\title{
Ethical Principles of the Islamic Faith - Insights for the Modern World
}

\author{
Iqbal Unus ${ }^{1} \&$ Cam Caldwell $^{2}$ \\ ${ }^{1}$ Georgetown University, International Institute of Islamic Thought, USA \\ ${ }^{2}$ University of Illinois - Springfield, USA \\ Correspondence: Cam Caldwell, University of Illinois - Springfield, USA
}

Received: August 15, 2017

Accepted: September 15, 2018

Online Published: September 20, 2018

doi:10.5430/bmr.v7n3p27

URL: https://doi.org/10.5430/bmr.v7n3p27

\begin{abstract}
The Islamic faith is viewed by many across the world with limited understanding and the image of Muslims has been tarnished by radical members of that religion whose actions do not reflect the religion's core beliefs. Because Muslims represent the world's second largest religious group with more than 1.6 billion adherents, understanding the ethical principles of the Islamic faith is in the interest of others throughout the world who live, do business, and/or associate with Muslims. In this paper we examine principles of the Islamic faith, as set forth in the Qu'ran and the Sunnah, and compare them with twelve other well-recognized ethical perspectives, comparing differences and similarities. We suggest that understanding the tenets of the Islamic faith will enable others to interact more effectively with Muslims as colleagues, business associates, and community members.
\end{abstract}

Keywords: Islamic ethics, comparative ethics, the Muslim context, Islamic faith, Islam in business

\section{Ethical Principles of the Islamic Faith - Insights for the Modern World}

At a time when the tenets of the Islamic faith are often poorly understood and Muslim radicals have been labeled as militant terrorists, Islamic believers and non-Muslims alike can benefit from a clarification of the moral and ethical foundations of the Islamic faith. Members of the Islamic faith constitute 1.6 billion people as of 2010 and $23 \%$ of the world's population (Lipka, 2015). As the world's fastest growing faith and as a religion characterized by many devout believers, the Islamic faith plays a major part in the world value system and its ethical and moral beliefs profoundly affect not only Muslims but those with whom they associate in a global economy (Bahammam, 2012).

The purpose of this paper is to briefly summarize the ethical and moral tenets of the Islamic faith and to place those beliefs in context with twelve other philosophically grounded ethical perspectives. By identifying the Islamic value system and ethical foundation, and by comparing its moral principles with those of other well-established ethical perspectives, this paper provides insights about Muslim beliefs that explain similarities and differences that form the ethical foundations of Islam. By clarifying the practical nature of the Islamic faith, this paper also contributes to the scholarly literature for those doing business with people of that faith and also provides insights for multinational employers doing business in predominantly Muslim cultures as well as any companies who employ members of the Islamic faith.

We begin by briefly summarizing core principles of the Islamic faith, citing scholarly research that puts its ethical and moral principles into perspective. We then compare the ethical principles of the Islamic faith with twelve other well-established ethical perspectives to identify similarities and differences between those perspectives and Islamic ethical principles. After identifying those similarities and differences, we present four practical implications of the paper and its contribution to the scholarly literature.

\section{Introduction: Understanding the Islamic Faith}

The Islamic faith "provides its followers a complete code of life by guiding all facets of human existence" (Mir, 2010, 69). Of the estimated 1.6 billion Muslims in the world between $85 \%$ and $90 \%$ are Sunni, with the remainder being Shia (BBC, 2013). Sunni live throughout the Arab world, and also in Turkey, Pakistan, India, Bangladesh, Malaysia, and Indonesia For the Middle Eastern countries about $90 \%$ of their population of Muslims are Sunnis in Saudi Arabia, Jordan, and Egypt. Iran has the largest proportion of Shia with about $90 \%$ of its population being of that group (BBC, 2013). Both Sunni and Shia view Muhammad as the last great prophet of Allah, the Islamic name of God, who was sent to guide man in the right path. 
Muhammad was born in $570 \mathrm{CE}$ to a well-respected family of the Quraysh tribe in the city of Mecca. He was orphaned as a young boy and was cared for by his uncle. According to Muslim tradition, Muhammad, like Moses, was under Allah's direct care and was prepared for his role as a prophet. . At the age of 40 in $610 \mathrm{CE}$, Muhammad is said to have received his first revelation which was the beginning of the Qur'an. The Qur'an is made up of revelations given to Muhammad through the archangel, Gabriel,

During his early ministry, Muhammad shared his beliefs privately and acquired a small following. Because of persecution of the followers of Muhammad, he and his followers were driven out of Mecca and migrated to Medina in $622 \mathrm{CE}$, which became a turning point in Muhammad's life. In Medina Muhammad created a secular constitution specifying the relations among the various existing communities-eventually creating an independent Muslim community and the first Islamic state. Despite the ongoing hostility of the Meccans, Muhammad and his followers, took control of Mecca in $630 \mathrm{CE}$, treated its citizens with generosity, and eventually unified the the population under Islam. Muhammad implemented social and religious reforms, and politically consolidated the Islamic community. ${ }^{3}$ By the time Muhammad died in 632 , his teachings had won the acceptance of almost the entire Arabian peninsula.

Muhammad's death created a schism among his followers over who should be his rightful successor. Shia regard Ali, the prophet's cousin and son-in-law, as the rightful successor. Sunni believe that the head of the Islamic faith should be chosen by consensus. All members of the Islamic faith share the common beliefs that Allah is one God, that Muhammad was his last prophet, that the Qur'an is the word of God for mankind, and all human beings will ultimately be resurrected and be held accountable for their beliefs and actions.

Muslims respect and revere Jesus Christ, who the Muslims refer to as Isa, as a great prophet and the Qur'an affirms his virgin birth. The Islamic faith affirms Christ's miracles but teaches that Christ was taken up to heaven and his likeness was put on another man who was taken and crucified (Medearis, 2008). The Qur'an makes reference to other Judaic prophets as well. Adam was the first of God's prophets and Muhammad is considered "the seal of the prophets" or the final prophet of God.

\section{Focus: Ethical Perspectives of Islamic Ethics}

The Qur'an sets forth clear but sometimes rigid caveats for leading a virtuous life and offers guidelines that put submission to Allah and obedience to the commandments as fundamental requirements for faithful believers (Anderson, 2016). The core beliefs of the Islamic faith center around self-mastery, discipline, and submission to the will of Allah. Beekun (1997, 20-29) identified five key axioms that govern the ethical philosophy of Islam.

Unity - The political, economic, social, and religious aspects of life are integrated into a homogenous whole that is internally consistent as well as consistent with the external universe. This unity is the vertical dimension of Islam.

Equilibrium - Each area of a person's life should be in balance. In order to produce the optimal social order, that balance is achieved through conscious purpose. This balance becomes the horizontal dimension of Islam.

$\square \quad$ Free Will - Man is empowered to act without external coercion within the parameters of Allah's creation and as a trustee of Allah on the earth.

$\square \quad$ Responsibility - Each person is accountable for his/her beliefs and actions.

$\square \quad$ Benevolence - One manifests his/her inner faith and commitment by kindness and by actions that benefit others without obligation or compulsion.

The Qur'an and prophetic tradition, or Sunnah, define the day-to-day value system of Islamic believers. Both the Qur'an and Sunnah are primary sources providing principles and guidelines for a virtuous Islamic life and are presumed by the faithful to be valid for all who embrace Islam (Beekun and Badawi 2005). The literal meaning of the word "Islam" is peace that is achieved through complete and unconditional submission to Allah's will in all spheres of life (Abuznaid 2006).

Ali and Al-Aali (2015) explain that Islamic ethics (IE) specifically opposes the creation of an organizational benefit at the expense of society and suggests a strong social responsibility and obligation for commerce. The Islamic concept of profit moderation rather than profit maximization suggests a counterpoint in the debate to the "free market" theory of ethics. Islam's emphasis on societal welfare, as compared to individual gain, reinforces the importance of corporate social responsibility (cf. Solomon, 199) which contrasts with the Milton Friedman (1970) argument that business exists solely to make a profit. Ali (2014) explained that Islamic ethics are virtue-based and 
reflect the intersection between good intention and virtuous conduct. Social responsibility encompasses obligations to protect the natural environment, honoring duties owed to stakeholders, and contributing to the general social welfare of society (Beekun, 1997, 38).

Benevolence, or ehsan in Arabic, sets the standard for ethical conduct. Distinguishing IE from free-market capitalism, Ali (2014) clarified that the emphasis of IE is on responsible conduct and the creation of societal good rather than personal self-interest. Islam's emphasis on creating a benefit for all and avoidance of harm to society meshes with Lennick and Kiel's (2011) definition of moral intelligence and the obligation to 1) do no harm, 2) create short-term value, and 3) create long-term value.

The axiom of benevolence impacts commercial dealings in six ways that reflect kindness, generosity, and a commitment to helping others in need.

1) If another person needs a thing, one should give it to him, making as little profit as possible. If a person forgoes the profit, that is all the better.

2) If a person purchases anything from someone who is poor or in financial need, it benefits the buyer to pay more than what would be the proper price, particularly if doing so creates an ennobling effect for that person in need. It is not praiseworthy to pay a rich man more than his due when that person is notorious for charging high prices.

3) One should act benevolently by giving a debtor more time to pay than is due, if necessary, and even make reductions in loans to provide relief to debtors.

4) People dissatisfied with goods purchased should have the right to return them as a matter of benevolence and fairness.

5) If one is a debtor, it is a graceful act to pay the debt without being asked to do so and before the debt is due, whenever possible.

6) When selling items on credit, one should be generous enough to refrain from pressing for payment when people are not able to meet stipulated terms.

These benevolence standards reflect the ideal in Muslim commercial dealings and are actions that honor Allah by treating others with kindness and respect.

Muhammad $(2012,116)$ noted that three principles govern economic exchange for commercial activities in Islam:

1) Freedom of Exchange: The Qur'an specifically endorses free trade and rejects the idea that free trade is forbidden.

2) Private Ownership: The Qur'an affirms that man has a right to work for that which he acquires as the legitimate fruits of his labors.

3) Security of Contracts: The Qur'an calls for the fulfillment and honoring of contracts and addresses both immediate and future contract payments.

Although business is encouraged in Islam, it must be done in compliance with principles set forth in the Qur'an and in Shariah law which specifically precludes underhanded, suspicious, or dubious business practices. The Qur'an admonishes the believers: "O ye who believe! Fulfill (all) obligations" (Qur'an 5:1). The Qur'an also quotes one of God's prophets telling his people, "Give, therefore, full measure and weight [in all your dealings], and do not deprive people of what is rightfully theirs" (Qur'an 7:85).

For all Muslims their actions or behaviors in the Islamic moral code are described in five different categories or classes which relate not only to business dealings but to all facets of Muslim life (Beekun, 1997, 29).

Fard - These are actions that are mandatory for every person claiming to be Muslim to perform. Such actions include praying five times a day, fasting, and giving alms to the poor or needy.

Mustahabb - These actions, while not obligatory, are highly recommended. These actions may include such things as additional voluntary prayers, fasting beyond Ramadan, and other benevolent actions not mandatory under the law.

Mubah - These actions are neither mandatory nor forbidden. For example, a Muslim may like a certain type of food that is not forbidden or participate in an activity that is not expressly forbidden.

Makruh -- These actions are not absolutely forbidden but are detested and considered inappropriate. For example, smoking is not expressly forbidden but is looked down upon. 
Haram - These actions are both unlawful under Shariah law and prohibited in the Qur'an or Sunnah and are likely to incur the punishment of Allah in the hereafter and legal punishment in the world. Adultery, murder, and drinking alcohol are examples of such prohibited behaviors.

For Muslims, what is lawful is both wholesome and pure. In addition, what is lawful is also moral and that which is unlawful is also immoral (Beekun, 1997, 30).

Islamic beliefs about women are often misunderstood by members of other cultures. Before the rise of Islam, Arabs lived in a patriarchal society. The Qur'an and Sunnah greatly enhanced the role of women, emphasizing the spiritual equality of all Muslims. The Qur'an gives women the right to choose their own husband, to own property, and to inherit wealth and designates that a husband has the obligation to financially support his wife. Muslim women may vote, obtain an education, enter into the professions, and serve in political office. The concept of honor killings of women who engage in premarital sexual relations is not supported by Islamic teachings. Female genital mutilation which is practiced in some countries where there are high Muslim populations is a cultural rather than a religious practice.

Youssef (2001) found that the Islamic Work Ethic (IWE) was a significant moderator between organization commitment and job satisfaction in a study of United Arab Emirates employees. In comparison with the Protestant Work Ethic's (PWE) focus on individualism and frugality, the IWE, focuses on intentions and purpose rather than on achieving profitable results (Youssef, 2001). . Both PWE and IWE "have a major focus on hard work, dedication, commitment, creativity, avoidance of wealth accumulation using unethical means, and cooperation at the workplace (Khan, et al., 2015, 235). The IWE encompasses a broad integration of philosophical, economic, social-psychological, and spiritual elements (Kazmi, 2016).

Khan and colleagues (2013) explained that IWE is heavily influenced by justice theory. The Muslim work ethic perspective views work as a means to achieve personal growth while enhancing social relationships (Ali \& Al-Owaihan, 2008). Musaleen and colleagues (2015) found that IWE mediated the relationship between trust and knowledge sharing in organizations and Murtaza and colleagues (2016) found that IWE positively impacted both knowledge sharing and extra-mile organizational citizenship behaviors. Kumar and Raduan (2010) found a public sector correlation between IWE and innovation within organizations.

The impact of IE and IWE on organizations focuses on honorable behaviors that seek the optimization of wealth creation in a manner that most benefits society. Comparing the IE with modern theories of governance, IE fits closely with stewardship theory, inasmuch as stewardship theory calls for honoring duties to all stakeholders and seeking to honor long-term wealth creation for society and all stakeholders. (Cf. Hernandez, 2008 \& 2012; Caldwell, 2012). Relating governance to leadership, Beekun and Badawi (2009) explain that the two primary roles of a leader are those of servant-leader and guardian-leader. Morally, leaders are both servants of their followers and guardians of the community - promoting justice, protecting against tyranny and oppression, and encouraging community members to increase their sense of duty toward Allah (Beekun \& Badawi, 2009, 15).

Within the Islamic model of leadership, " leaders pursue a vision of creating a society that is just, welfare-oriented, egalitarian, and free from discrimination, exploitation, and oppression" (Mir, 2010, 69). The moral basis of leadership in Islam is rooted in the belief in and the willing submission to Allah (Beekun \& Badawi, 2009, 17). From a leadership perspective, IE has a linkage to transformational leadership (Mir, 2010), principle-centered leadership (Covey, 1992) and virtuous leadership (Caldwell, Hasan, \& Smith, 2015). Muhammad is described in the Qur'an (68:4) as "a virtuous model for all times and a moral and ethical leader whose life is founded on correct principles and who cares about both the individual and the welfare of society."

Mir (2010) identified five fundamental attributes that characterize leadership in Islamic society, affecting the micro-level of the family, the meso-level of communities and neighborhoods, and the macro-level of cities or nations.

1) Piety - Reverence, awe, or the fear of God, or taqwa, emphasizes the importance in Islam of consciousness of Allah in all aspects of Muslim life and is a key component of righteous leadership.

2) Humility - For a Muslim to aspire to leadership or the acquisition of authority is an inappropriate behavior. Leaders do not seek followers but followers seek them out.

3) Social Responsibility - The supreme responsibility of a leader in Muslim society is the welfare of followers and the collective good of the community. The welfare of others takes precedence over the leader's own welfare. 
4) Self-Development -- The leader is on a constant path in search of self-improvement and spiritual renewal. Self-awareness requires that a leader be vigilant about his/her own shortcomings, controlling emotions, and responsible behavior. The word, jihad, means doing one's utmost and the leader's role is to model self-improvement behavior.

5) Mutual Consultation - Muslim leaders make decisions after considering the advice of others, examining evidence, and considering diverse perspectives. Leaders seek for consensus and to incorporate the collective wisdom of others.

These five attributes enable leaders to seek noble goals, the betterment of others, and the integration of the secular and the sacred in the lives of those being served. The role of the Muslim leader is to be a coach, an exemplar, and a developer of others - taking people from where they are to a higher and nobler state and bringing them closer to Allah (Beekun \& Badawi, 2009). It is in honoring this moral purpose of improving the lives of followers that Muslim leaders incorporate IE into their leadership actions.

\section{Comparison: Islamic Ethics and Other Ethical Perspectives}

Although ethics are the moral principles that differentiate right from wrong, (Khan, et al., 2013), there are a multitude of often-cited philosophical justifications for ethical behavior - with each ethical perspective calling out a slightly different moral choice or outcome (Brady,1999). For example, Hosmer (1994 \& 1995) identified a set of well-respected business ethics perspectives and noted that each of those perspectives suggested a slightly different ethical outcome -- based upon the philosophical roots upon which each ethical perspective was founded. Building on Hosmer's work, Table 1 identifies twelve different ethical perspectives and compares and contrasts them with Islamic ethics.

Table 1. Twelve Ethical Perspectives and Their Ethical Implications

\begin{tabular}{llll}
\hline $\begin{array}{l}\text { Ethical } \\
\text { Perspective }\end{array}$ & Basic Summary & $\begin{array}{l}\text { Organizational } \\
\text { Impacts }\end{array}$ & $\begin{array}{l}\text { Similarities and Ethical Implications for } \\
\text { Differences with Islamic Business } \\
\text { Ethics (IE) }\end{array}$
\end{tabular}

Self-Interest Society benefits Seeks to optimize IE focuses less on When doing business, (Protagoras) when we pursue long-term wealth self-interest and more identify the benefits to self-interest without creation. on overall benefits to society overall, in addition encroaching on society. Both respect the others' rights. need to honor others' others also merit inclusion. rights.

\begin{tabular}{|c|c|c|c|c|}
\hline $\begin{array}{l}\text { Utilitarian } \\
\text { Benefit } \\
\text { (Bentham } \\
\text { Mills) }\end{array}$ & $\begin{array}{l}\text { A law or act is } \\
\text { "right" if it leads to } \\
\text { more net social } \\
\text { benefits } \\
\text { harms. }\end{array}$ & $\begin{array}{l}\text { Recognizes the } \\
\text { need to identify } \\
\text { costs, benefits, } \\
\text { and impacts of } \\
\text { choices. }\end{array}$ & $\begin{array}{l}\text { IE acknowledges the } \\
\text { importance of avoiding } \\
\text { harm and optimizing } \\
\text { benefits to society and } \\
\text { the entire community. }\end{array}$ & $\begin{array}{l}\text { Emphasize documentation } \\
\text { of costs and benefits to } \\
\text { society in entering into } \\
\text { collaborative agreements. }\end{array}$ \\
\hline $\begin{array}{lr}\text { Personal } & \text { Virtues } \\
\text { (Plato } & \& \\
\text { Aristotle) } & \end{array}$ & $\begin{array}{l}\text { Standards must be } \\
\text { adopted to govern } \\
\text { relationships and } \\
\text { articulate virtuous } \\
\text { behaviors. }\end{array}$ & $\begin{array}{lr}\text { Organizations } \\
\text { must } & \text { govern } \\
\text { according } & \text { to } \\
\text { correct } & \\
\text { principles. }\end{array}$ & $\begin{array}{l}\text { IE emphasizes the } \\
\text { importance of personal } \\
\text { virtues but also focuses } \\
\text { on intentions rather } \\
\text { than outcomes. }\end{array}$ & $\begin{array}{l}\text { Identify the underlying } \\
\text { intentions of a commercial } \\
\text { venture and the values } \\
\text { upon which outcomes are } \\
\text { sought. }\end{array}$ \\
\hline $\begin{array}{l}\text { Religious } \\
\text { Injunction } \\
\text { Augustine) }\end{array}$ & $\begin{array}{lr}\text { Compassion } & \text { and } \\
\text { kindness must } & \text { mus } \\
\text { accompany honesty, } \\
\text { truthfulness, and } \\
\text { temperance. }\end{array}$ & $\begin{array}{l}\text { Honoring } \\
\text { relationships } \\
\text { equates with } \\
\text { interpersonal and } \\
\text { respect and } \\
\text { kindness. }\end{array}$ & $\begin{array}{l}\text { IE is heavily dependent } \\
\text { on the Qur'an and } \\
\text { Sunnah and those } \\
\text { religious requirements } \\
\text { are considered } \\
\text { profoundly important. }\end{array}$ & $\begin{array}{l}\text { As a matter of extreme } \\
\text { importance, understand } \\
\text { the tenets of the Islamic } \\
\text { faith and their impacts on } \\
\text { business activities } \\
\text { including the } \\
\text { commandment to fulfill all } \\
\text { obligations and to not } \\
\text { deprive people of what is } \\
\text { rightfully theirs. }\end{array}$ \\
\hline
\end{tabular}




\begin{tabular}{llll}
\hline Government & $\begin{array}{l}\text { Established rules } \\
\text { Requirements }\end{array}$ & $\begin{array}{l}\text { The law sets forth } \\
\text { should be honored obligations that ing the law and Recognize the implications }\end{array}$ \\
$\begin{array}{l}\text { (Hobbes } \\
\text { Locke) }\end{array}$ & $\begin{array}{l}\text { and complied with protect individual are important of the Qur'an and Sunnah } \\
\text { in dealings with rights. }\end{array}$ & $\begin{array}{l}\text { elents of IE. Religion on legal issues, as well as } \\
\text { has the force of law in government requirements. } \\
\text { their lives. }\end{array}$
\end{tabular}

Universal Rules Inspired (Kant)

\section{govern}

rules Universal rule resulting in greater good for leaders. society.

action, and values impact

In the IE, their religion establishes the foundation for universal rules and achieves the greater good.

Individual

Rights

(Rousseau

An articulated list of protected rights

Organizations are and ensures individual obligated

Jefferson)

freedom

and

protects

individuals. to the rights of individuals duties

to

in society are set forth
Acknowledge and respect the religious principles and rules that form the basis of the Islamic faith.

members.
Economic Efficiency (Adam Smith)

Seek the maximum Acknowledges the output of needed importance of goods and the wealth creation maximization of and value. profits.

Avoid taking any Organizations

Distributive Justice (Rawls) actions that harms owe individuals the least of us in fair treatment at any way. all times.
Contributing Liberty (Nozich)

Avoid actions interfere others' self-fulfillment and development.

Ethic of Care (Gilligan)

Emphasize
honoring
relationships,
caring for others
and
responsible.

Ethic Self-Mastery (Maslow)
Honors interpersonal relationships and honoring obligations others. of Seek to achieve Acknowledges personal importance self-mastery and helping self-actualization to individuals thereby serve the become their best world
IE is justice-based and

Wealth creation and value is viewed in terms of benefits to society and contribution to the ability of society to comply with Islamic tenets.

IE views justice as procedural rather than distributive. The rights of the poor are respected.

Identify benefits for all of society and focus on procedural justice and fit with Islamic tenets.

Stress the benefits accruing to society and respect for principles of the Islamic faith in defining economic wealth creation.

Identify rights and primary identified as of Islamic faith.

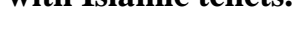

Describe the benefits accruing to those involved with commercial dealings, including benefits to employees.

IE emphasizes the Recognize and honor importance of caring interpersonal relationships, about others and obligations, and honoring relationships responsibilities in dealing to and responsibilities. with others.
IE emphasizes the Acknowledge the of importance self-discipline, of importance of business programs, policies, and systems that promote employee growth and acquisition of qualities employee
that enhance service to self-mastery. others and society.

As indicated by Table 1, IE honors the religious injunctions of the Qur'an and places great importance on examining the costs and benefits of ethical decisions on society, rather than simply on a narrow group of stakeholders. At the same time, IE also focuses on helping individual organizational members to become their best while seeking to protect their rights as individuals. 
In his review of IE, Beekun (1997, 9-19) compared the Islamic perspective with ethical relativism, utilitarianism, universalism, rights, distributive justice, and eternal law. Distinguishing IE from the moral codes of other religions, Beekun $(1997,18)$ explained that the Islamic faith "stresses that piety is not achieved by relinquishing the life of this world .... (but) (i)t is through the active participation in the day-to-day affairs of this world and through the struggle in this life against evil that a Muslim proves himself." For the believers of the Islamic faith, "(t)he eternal law in Islam is not limited to matters of religion; it permeates all aspects of a Muslim's life" (Beekun, 1997, 19).

Summarizing the IE system, Beekun $(1997,19-20)$ explained that it consists of eight fundamental elements:

1) Actions and decisions are judged to be ethical depending on the intention of the individual.

2) Good intentions followed by good actions are considered as acts of worship. Lawful intentions or halal, cannot make forbidden actions, or haram, acceptable.

3) Islam allows an individual the freedom to believe and act as (s)he desires, but not at the expense of accountability and justice for those beliefs and actions.

4) Belief in Allah endows individuals with complete freedom from anything or anybody except Allah.

5) Decisions or choices that benefit the majority or a minority are not necessarily ethical in themselves. Ethics is not a numbers game.

6) Islam incorporates an open system approach to ethics, not a closed or self-oriented system. Egoism has no place in Islam.

7) Ethical decisions are based upon a simultaneous reading of the Qur'an and the natural universe.

8) Unlike the ethical systems advocated by many other religions, Islam encourages humankind to experience purification of the soul, or tazkiyah, through active participation in this life. By behaving ethically in the midst of the tests of the material world, or dunya, Muslims prove their commitment to Allah.

As Beekun (1997,2) explained, followers of the Islamic faith view ethics as governing all aspects of life and are essential for virtuous living.

"The conditions for everlasting success or falah in Islam are the same for all Muslims-whether in conducting their business affairs or in carrying out their daily activities. Without specifying any situational context, Allah describes people who attain success as those who are "inviting to all that is good (khayr), enjoining what is right (ma'ruf) and forbidding what is wrong (munkar)."

Thus, the eternal law of Allah, as reflected in the Qur'an, the Sunnah, and natural law permeates all elements of the Muslim life.

\section{Contributions of the Paper}

Because of the importance of the Islamic faith and its 1.6 billion followers in an increasingly connected global economy (Friedman, 2007), understanding the ethical philosophy and underlying tenets of IE has significant value in the world marketplace. We suggest that our paper makes four significant contributions.

1) We provide a brief explanation of the beliefs of the Islamic faith that can be used by practitioners and scholars to relate more effectively with modern day Muslims. We articulate a brief summary of the foundations of the Islamic faith and its fundamental beliefs as set forth in the Qur'an and Sunnah, the foundation traditions of the Muslim faith.

2) We provide a brief summary of IE, or Islamic Ethics, citing a variety of scholarly academic sources that incorporate IE within a business context. We cite the research of Islamic scholars who have published extensively about IE and integrate that research in our summary.

3) We compare and contrast IE with twelve well-recognized ethical perspectives and identify similarities between those perspectives and IE. We note that IE most closely incorporates the ethical dimensions of Religious Injunction, which would be highly predictable given the sometimes strict requirements of the Islamic faith. We note that IE also includes elements of the other ethical perspectives and is also committed to enhancing individual and societal growth and preserving personal freedoms within the framework of the Muslim faith.

4) We identify the practical benefits to society of the Islamic faith in the $21^{\text {st }}$ century modern world. We note that within a business context, scholarly research confirms that IE and IWE contribute to knowledge sharing, organizational citizenship behavior, and innovation in organizations where those ethical elements 
of the Islamic faith have been examined empirically. Those who practice the Islamic faith do so with a commitment to creating a better world, serving society rather that personal self-interest, and honoring their relationships to others and to Allah.

\section{Conclusion}

Although the image of the Muslim community has often been impacted by the beliefs and actions of the radical Muslims, the Islamic faith as set forth in the Qur'an and the Sunnah is a deeply devout set of religious principles, moral standards, and ethical beliefs that centers on the importance of a life devoted to Allah and a commitment to personal excellence and virtue. The Islamic faith clearly emphasizes the importance of fairness, justice, and equality as foundation moral principles. Practices attributed to the Islamic faith are often accompanying characteristics of regional or national cultures, rather than defining characteristics of Islam.

Those who practice the Islamic faith as true believers seek to obey the laws of God - whom they call Allah, but who they acknowledge is called other names by other religions. Muslims seek to honor Allah and to submit themselves completely to His well in their lives - and that honoring Allah requires that they work for the welfare of society, their communities, their families, and their own self-development. Understanding the principles of the Islamic faith can enable others not of that faith to appreciate the commitment of Muslims to doing what is right, to treating others fairly in business dealings, and to creating a world devoted to the pursuit of peace and justice.

\section{References}

Abbas, J. A. (2014). Business ethics in Islam. Cheltenham, UK : Edward Elgar Publishing.

Abuznaid, S. (2006). Islam and management: What can be learned? Thunderbird International Business Review, 48(1), 125-139. https://doi.org/10.1002/tie.20089

Ali, A. \& Al-Aslie, A., (2015). Marketing and ethics: What Islamic ethics have contributed and the challenges ahead. Journal of business ethics, 129(4), 833-84. https://doi.org/10.1007/s10551-014-2131-x

Ali, J. A., \& Al-Owaihan, A. (2008). Islamic work ethic: A critical review. Cross Cultural Management: An International Journal, 15(1), 5-19. https://doi.org/10.1108/13527600810848791

Anderson, M. R., (2016). The Qur'an in context: A Christian exploration. Downers Grove, IL: IVP Academic.

Bahammam, F. S., (2012). Muslim faith. Riyadh, Saudi Arabia: Modern Guide.

Beekun, R. I., (1997). Islamic business ethics. Herndon, VA: International Institute of Islamic Thought.

Beekun, R. I., \& Badawi, J. A. (2005). Balancing ethical responsibility among multiple organizational stakeholders: The Islamic perspective. Journal of business ethics, 60(2), 131-145. https://doi.org/10.1007/s10551-004-8204-5

BBC News. (2013). Sunnis and Shia in the Middle East. December 19, found online on June 21, 2016 at http://www.bbc.com/news/world-middle-east-25434060.

Brady, F. N. (1999). A systematic approach to teaching ethics in business. Journal of business ethics, 19(3), 309-318. https://doi.org/10.1023/A:1005904915906

Caldwell, C. (2012). Moral leadership: A transformative model for tomorrow's leaders. New York: Business Expert Press. https://doi.org/10.4128/9781606492543

Covey, S. R. (1992). Principle-centered leadership. Denver, CO: Fireside Press.

Friedman, M. (1970). The social responsibility of business is to increase its profits. The New York times magazine, September 13.

Friedman, T. L. (2007). The world is flat 3.0: A brief history of the twenty-first century. New York: Picador.

Harney, J. (2016). How do Sunni and Shia Islam differ?” New York times, January $3^{\text {rd }}$, found online on June 18, 2016 at http://www.nytimes.com/2016/01/04/world/middleeast/q-and-a-how-do-sunni-and-shia-islam-differ.html?_r=0.

Hernandez, M. (2012). Toward an understanding of the psychology of stewardship. Academy of management review, 37(2), 172-193. https://doi.org/10.5465/amr.2010.0363

Hernandez, M. (2008). Promoting stewardship behavior in organizations: A leadership model. Journal of business ethics, 80(1), 121-128. https://doi.org/10.1007/s10551-007-9440-2

Hosmer, L. T. (1994). Strategic planning as if ethics mattered. Strategic management journal, 15, 17-34. https://doi.org/10.1002/smj.4250151003 
Hosmer, L. T. (1995). Trust: The connecting link between organizational theory and philosophical ethics. Academy of management review, 20(2), 379-403. https://doi.org/10.5465/amr.1995.9507312923

Kazmi, A. (2016). Business ethics in Islam. Business ethics quarterly, 26(2), 257-60. https://doi.org/10.1017/beq.2016.22

Khan, K., Abbas, M., Gul, A., \& Raia, U. (2015). Organizational justice and job outcomes: Moderating role of Islamic work ethic. Journal of business ethics, 126(2), 235-246. https://doi.org/10.1007/s10551-013-1937-2

Kumar, N. \& Rose, R. C. (2010). Examining the link between Islamic work ethic and innovation capability. Journal of management development, 29(1), 79-93. https://doi.org/10.1108/02621711011009081

Lennick, D., \& Kiel, F. (2011). Moral intelligence: Enhancing business performance and leadership success 2.0. Upper Saddle River, NJ: Prentice Hall.

Lipka, M. (2015). Muslims and Islam: Key findings in the U.S. and around the world. Washington D.C.: Pew Research Center. December 7 found online on June 22, 2016 at http://www.pewresearch.org/fact-tank/2015/12/07/muslims-and-islam-key-findings-in-the-u-s-and-around-theworld/.

Medearis, C. (2008). Muslims, Christians, and Jesus: Gaining understanding and building relationships. Cincinnati, $\mathrm{OH}$ : Bethany House Publishers.

Mir, A. M. (2010). Leadership in Islam. Journal of leadership studies. https://doi.org/10.1002/j1s.20180

Muhammad, A. U. (2012). What constitutes 'business ethics' in Islam? Journal of business \& economic research, 7(1), 115-123.

Mursaleen, M., Saqib, L., Roberts, K. W., \& Asif, M. (2015). Islamic work ethics as mediator between trust and knowledge sharing relationship. Pakistan journal of commerce \& social sciences, 9(2), 614-640.

Murtaza, G., Abbas, M. Raja, U., Roques, O., Khalid, A. \& Mushtaq R. (2016). Journal of business ethics, 133(2), 325-333. https://doi.org/10.1007/s10551-014-2396-0

Solomon, R. C. (2003). Ethics and excellence: Cooperation and integrity in business. New York: Oxford University Press.

Yousef, D. A. (2001). Islamic work ethic - A moderator between organizational commitment and job satisfaction in a cross-cultural context. Personnel Review, 30(2), 152-165. https://doi.org/10.1108/00483480110380325 